\title{
Strategies on how to teach neologisms for EFL students majoring in economics
}

\author{
Elena M. Galishnikova - Svetlana N. Khalevina - Olga V. Meshcheryakova
}

\section{DOI: 10.18355/XL.2017.10.04.29}

\begin{abstract}
This paper discusses some strategies on how to teach neologisms for EFL students majoring in Economics. The importance of interpreting newly coined words and phrases is that students come across them in a variety of sources and can find it difficult to interpret them correctly. The aim of this study is to develop, theoretically substantiate and offer practice-oriented tasks based on authentic linguistic material that enhances the learning skills of understanding and translating neologisms. The present study was designed to test the hypothesis that an adequate understanding and translation of neologisms from English into Russian becomes possible only after the EFL learners master the understanding of their origin and formation. The findings of this study indicate the effectiveness of the proposed step-by-step action plan for teaching EFL students.
\end{abstract}

Key words: neologism, lexical unit, calquing, abbreviation, acronym.

\section{Introduction}

The modern world can be characterized by the growth of the number of discoveries in various fields of human activity, which serves a strong impetus to enrichment and enlargement of the lexis of many languages. According to the survey carried out by Global Language Monitor, a new word appears in the English language every 98 minutes (Payack, 2008). The Oxford English Dictionary has been enlarged by more than 600 new words, phrases, and senses this quarter (2017), including bug chaser, chantoosie, gin daisy, and widdly (http://public.oed.com/the-oed-today/recentupdates-to-the-oed/). Language needs to develop - some words naturally become obsolete, they are no longer in active use in speech and writing, and some replace them. According to estimates of specialists, each year, 800 to 1,000 new words can be added to English language dictionaries, this number exceeds the number of words added in any other language of the world (for example, more than 90,000 words were added in the 20th century). Editors of the third edition of the Oxford English Dictionary (OED), to be completed by 2037, estimate that the rate of inclusion of new words into the OED is about 4,000 per year. As for 2014, more than 2,500 new words were added into the OED (https://atkinsbookshelf.wordpress.com/tag/how-manywords-enter-the-english-language-each-year/). However, many English textbooks and teaching materials that are used in Russia for teaching English as a foreign language contain outdated or non-standard examples and do not keep pace with the rapidly changing modern language, which is universally recognized as the language of international communication.

Rapid changes in technology and science, economics and communication as well as the expansion of intercultural interaction, serve as the main factors affecting changes happening in the lexicon of the English language.

Such dramatic changes cannot be ignored by educators teaching English as a foreign language. As experience shows, the ability to obtain, process and transfer information, from authentic texts, critical for professional communication, should be regarded as one of the factors determining successfulness and effectiveness of professional activity of graduates who are going to work in international and multinational companies. Such authentic texts often contain new words introduced into a language, by a variety of processes. These are called neologisms. Understanding neologisms can serve as a means of developing intercultural

XLinguae, Volume 10 Issue 4, October 2017, ISSN 1337-8384, eISSN 2453-711X 
understanding, helping graduates avoid cultural blunders and giving them a better insight into cultural background and motive of their potential business partners.

Therefore we believe that it is necessary to introduce learning activities based on authentic texts, placing special emphasis on understanding and translation of neologisms into Russian.

The importance of this issue comes from the fact that students come across neologisms in different sources and can find it difficult to interpret them correctly. The main difficulty of understanding the meaning of a neologism is that the new word has not been added to dictionaries yet. Though many famous dictionaries have a special section for neologisms (the Oxford English Dictionary), when it comes to oral communication, dictionaries are not available immediately and students need to be aware of ways or strategies of interpreting new words or phrases they hear. Neologisms are created constantly in language as a natural part of language evolution. Dealing with language evolution is part of learning a foreign language. Dealing with unknown vocabulary is step number one. Doing that will help with dealing with words that do not occur in the dictionary yet.

Neologisms tend to pass through the following stages (Lavrova, 2010):

- Unstable - extremely new, being proposed, or being used only by a small subculture (also known as Protologisms);

- Diffused - having reached a significant frequency of use, but not yet having gained widespread acceptance;

- Stable - having become recognizable, being en vogue, and perhaps, gaining lasting acceptance;

- Dated - the point where the word has ceased being novel, entered formal linguistic acceptance and, even may have passed into becoming a cliché;

- Passe - when a neologism becomes so culturally dated that the use of it is avoided because its use is seen as a stigma: a sign of being out of step with the norms of a changed cultural tradition, perhaps, with the term dropping from the lexicon altogether.

The subject matter of the study is the process of teaching English to EFL students at the non-linguistic higher school.

The scope of the study is developing strategies on how to teach neologisms for EFL students majoring in Economics.

The present study was designed to test the hypothesis that an adequate understanding and translation of neologisms from English into Russian becomes possible only after the EFL learners master an understanding of the origin and formation of neologisms.

In accordance with the subject, purpose and hypothesis, the research objectives are as follows:

- to reveal and describe the problems related to defining neologisms, interpreting and translating them into Russian;

- to categorize the neologisms according to the standpoint of their formation and the criteria of use;

- to develop a step-by-step action plan for teaching EFL students how to understand and translate neologisms in the economic discourse;

- to identify and select teaching materials for the implementation of the developed step-by-step action plan in the educational process at the non-linguistic higher school and to test experimentally their effectiveness.

\section{Review of Literature}

There are a variety of approaches to defining neologisms. By definition, neologisms are a lexical layer in the language that is characterized by temporary "novelty connotation" (Zabotkina, 1989). According to the Lingo-didactic 
encyclopedic dictionary a neologism is a word or phrase which is created to denote a new object or express a new concept. According to Vinogradov (1969) "neologisms are new words and meanings fixed in the language which are used to name new objects of thought". Therefore, neologisms appear in the language more than once and are functionally fixed in it for a certain period of time. As some authors have stated (Arnold, 1996; Slepovich, 2004; Alekseeva, 2008), these new words differ by duration and frequency of use. Fischer (1998) and Rets(2014) consider neologisms as words stylistically marked by the novelty of the usage. In accordance to structural theory (Sari, 2013) neologisms are completely new words with a new form (e.g. authorisms). From the point of view of etymological theory neologisms are defined as "words which already exist in a language but developed a new meaning over the recent years" (Cook, 2010; Rets, 2014).

Neologisms can be considered a mirror of linguistic development which shows how the language adapts to the changing environment of its usage. The source of lexical innovation is linguistic usage. Processes of globalization have changed the conditions in which English is functioning, having made it an international language of space, finance, trade, aviation, science, and culture. In the modern neology of the English language, we can identify two main areas of research: 1) the study of specifics of linguistic innovation and 2) a research agenda for lexicographic research of neologisms. The lexicographic agenda of neology has been actively developed in the USA and Great Britain (Barnhart, 1985; Algeo, 1990; Ayto, 1995).

The majority of research studies on neologisms belong to the field of linguistics (Cook, 2010; O'Dell, 2016; McDonald, 2005) rather than methodological aspects of language teaching, though these two fields are interconnected in a number of ways. This research project is interdisciplinary and synthesizes the two areas of study which increases its theoretical and practical relevance.

There are several ways of forming neologisms that we can single out:

1. Neologisms are formed by means of word formation and compounding. In this case the most frequently used suffixes are -tion, -ism for nouns and -ize for verbs. The suffixes -tion and -ism are productively used to form words denoting new concepts in political science and economics, for example, self-disruption (a major change made by a company to its traditional activities); brandalism (the encroachment of ads, logos, and other types of corporate branding into public and traditionally noncommercial spaces, or the dissemination of corporate messages through methods or mediums not typically used for marketing purposes).

Another productive verbal suffix is -ize, for example, to bulletize (to use bullets in Microsoft PPP or Word); to calendarize(to schedule appointments); to dollarize(replacing a national currency with the US dollar);; to genericize (to produce staple goods).

Prefix de- is frequently used to create new words. It is used as a euphemistic tool attempting to deflect from the negativtiy of the processes being described. It emphasises the positive word by adding a negative prefix. For example, to deproliferate (to shrink); decruitment (dismissal); de-risk (to reduce risk); demote (opposite to promote), delayering (reduction of management levels in a company, a demuter (somebody who works from home).

Such neologisms as know-how; just-in-time (delivery on time without storing goods at a warehouse); downsizing orrightsizing (making employees redundant or reducing the number of management levels) are compound nouns and appeared in the English language as a result of compounding.

2. Neologisms can appear because familiar words develop a new meaning, for example, empowerment (means 'delegating authority to employees', consists of 'empower (n) + ment (suffix)); contagion (means 'describing the spread of an economic or financial crisis', originates from late Middle English (denoting a

XLinguae, Volume 10 Issue 4, October 2017, ISSN 1337-8384, eISSN 2453-711X 
contagious disease): from Latin contagio(n), from con-'together with' + the base of tangere 'to touch').

3. Calquing or direct borrowing can also be a source of neologisms, for example, maquiladora (the term "maquiladora" originates from the Spanish word "maquila" which historically refers to the payment millers receive from farmers for grinding corn into meal, or adding value; a bureau de change (the term is originally French).

4. Abbreviations and acronyms add a lot of new words to the English lexicon: $\mathrm{COO}$ (Chief Operation Officer); GM (General Manager); NASDAQ (National Association of Securities Dealers Automated Quotation); OPEC (Organization of the Petroleum Exporting Countries); DExEU (Department for Exiting European Union); $B$-unit (Barclays currency unit).

5. Conversion is another productive way to form neologisms, for example, Google-to google; condition - to condition; an architect - to architect; transition - to transition; to buy - buy.

6. Euphemisms also serve a source of neologisms in the English language, for example, career-change opportunity (dismissal).

Zhou (2016) also distinguishes traditional rules of word formation such as clipping and analogy. Clipping is the reduction of a word to one of its parts. The most common type is apocope in which the beginning of the prototype is retained (for example, vert (vertical), techie (technician), and sig (signature)).Final clipping or apheresis retains the final part of the prototype: varsity (university), a net (Inter or intra net). Syncope is the word with the middle part of it left out: maths (mathematics) and specs (spectacles). Neologisms can be formed by analogy with existing words. Analogy is a cognitive process of transferring information or meaning from a particular source to another target, or a linguistic expression corresponding to such a process. Such word asteleholic isformed on the analogy of workaholic. Other analogous neologisms are color analogy including grey collar, pink-collar, new collar, they are shaped from white collar; antonym analogy brain gain is formedfrom brain drain, down market from upmarket, etc. As a result, neologisms formed by analogy abound in large numbers (http://www.davidpublisher.com/Public/uploads/Contribute/570f3d2ade3b9.pdf).

The younger generation generally has a positive attitude towards the emergence of neologisms, the older generation generally doesn't share this position. People who have high levels of education consider neologisms a normal process of language development and can easily introduce them into speech and text. Social science scholars find it more difficult to accept new words than technical professionals. This may be because new words constantly appear in the technical sphere so? This is a specific area where there are no word analogues. The emergence of neologisms, on the one hand, is a natural process, as new words appear to address developments in the economic, political and cultural spheres.

Rets (2016) traces the advantages of teaching neologisms in English language classroom: practicing spoken English; reflecting on new cultural experience of English-speaking society and the current trends of its development; using authentic learning materials; developing students' critical thinking skills.

Yashina and Polyakova (2017) reported on sixbasic methodological principles of students' acquaintance with the rules of word formation, neologisms and their application to practice:

1. Introduce neologisms in English classes at early-stage teaching at the university. Undoubtedly, reading authentic business literature, including newspapers and magazines is possible when students have an Intermediate or Advanced level of the English language. However, it also makes sense to introduce some words or draw learners' attention to neologisms in texts on general topics at Pre-Intermediate levels. 
2. Use contextual clues to learn these lexical units. This condition is essential, since without context, many neologisms lose their meaning. In addition, the context simplifies the process of memorizing and understanding of the word. From a methodological point of view, it is more convenient for the learner to work with the text rather than with a separate lexical unit.

3. Discuss some theoretical aspects of word formation with students. Some special classes can be devoted to theoretical material or relevant information can be introduced gradually, during several sessions. However, an integrated approach might be more efficient to teach vocabulary as opposed to organising a separate lesson on neologisms and teaching them in isolation. The integrated approach might provide students with a bigger picture of language and help them practice various groups of lexical units at the same time.

4. The discussion of specific cases of the use of neologisms should concern not only the lexical meaning of these words, but also their internal structure, stylistic affiliation and connotation. The attempt to trace the etymology of words, analysis of collocations and stylistic affiliation result in better understanding the semantics of lexemes, and also contribute to memorization.

5. Work on neologisms is closely connected with the development of linguistic and intercultural competences, therefore exercises designed to develop skills dealing with neologisms in business discourse should be aimed at acquiring knowledge about the language system and the culture of the country and its inhabitants. Exercises on understanding of how neologisms fit into the overall system of work on the development of a foreign language and involve many skills, including higher order thinking skills of analysis and evaluation.

6.To be able to recognize and understand neologisms, the following types of tasks are recommended: analysis of the internal form and/or etymology of the neologism; determining the meaning of the neologism according to the context; defining the term of neologism; analysis of the collocations; making up examples with neologisms; finding and analyzing neologisms in the authentic texts; formation of words on a given topic; comparison of similar neologisms in several languages; determination of the way of word formation.

\section{Materials and Methods}

\subsection{Research methods}

The following methods have been used in our research: analysis and synthesis, following every part of the work, descriptive method and the method of statistical analysis, methods of typological and lexicological analysis, interview, comparative method, deductive and inductive methods of investigation and generalising the retrieved facts and data, some elements of componential, contextual, distributional and dictionary definition analysis.

\subsection{Research Stages}

The research has been conducted in three stages.

The first stage involved: studying the degree of scientific development of the problem; identifying the subject matter, the scope and the purpose of the research; developing the hypothesis; formulating the research objectives; defining the methods adequate for the purpose and objectives of the study; revealing and describing the problems related to defining neologisms, interpreting and translating them into Russian, categorizing the neologisms according to: the standpoint of their formation; the criteria of use.

At the second stage we theoretically justified and developed. a step-by-step action plan for teaching EFL students how to understand and translate neologisms in the economic discourse. Learning materials for the implementation of the developed

XLinguae, Volume 10 Issue 4, October 2017, ISSN 1337-8384, eISSN 2453-711X 
step-by-step action plan in the educational process at the non-linguistic higher school were selected.

The third stage included an experiment to test the effectiveness ofthe stepby-step action plan;systematization and analysis of the results; drawing conclusions.

\section{Results and discussion}

Having studied and analysed the works by researchers in the field of translation studies (Meshkov, 1986; Lopatin1973), theory and methodology of professional education (Sokolova1983), as well as our experience, we identified the major stages of work with neologisms in the English language learning environment at a non-linguistic higher school.

Table 1 illustrates a step-by-step action plan, which is used when teaching EFL students how to understand and translate neologisms. This, have brought certain benefits when translating neologisms in the economic discourse.

Table 1: Step-by-step action plan for an adequate understanding and translation of neologisms in the economic discourse

\begin{tabular}{|c|c|}
\hline Stage & Actions \\
\hline $\begin{array}{l}\text { 1. Pre-translation } \\
\text { analysis }\end{array}$ & $\begin{array}{l}\text { - Elicit a neologism in the text } \\
\text { - Identify what part of speech and function neologism } \\
\text { exercise in the sentence } \\
\text { - Identify stylistic and genre peculiarities of the text as } \\
\text { well as an overall context }\end{array}$ \\
\hline 2. Equivalent search & $\begin{array}{l}\text { Try to find the equivalent in free bilingual dictionary, } \\
\text { including regularly updated online versions of } \\
\text { dictionaries (http://multitran.ru, http://multilex.ru, } \\
\text { http://www.oxforddictionaries.com/, } \\
\text { https://glosbe.com/ and others) }\end{array}$ \\
\hline 3. Definition search & $\begin{array}{l}\text { Try to find a definition of the search word in English } \\
\text { in free monolingual dictionaries, including regularly } \\
\text { updated online versions of dictionaries } \\
\text { (http://www.oxforddictionaries.com/, } \\
\text { http://www.merriam-webster.com/, https://glosbe.com/ } \\
\text { and others). } \\
\text { Translate the neologism on the basis of its definition } \\
\text { considering an overall context provided that the } \\
\text { definition is found and the neologism is registered in } \\
\text { the dictionary }\end{array}$ \\
\hline $\begin{array}{l}\text { 4. Defining the way } \\
\text { of the formation of } \\
\text { neologisms }\end{array}$ & $\begin{array}{l}\text { - Analyse the neologism towards defining the way of its } \\
\text { formation (affixation, compound, meaning extension, } \\
\text { phoneme, conversion, abbreviation, phraseology, etc.) } \\
\text { unless there is a neologism in dictionaries or in case } \\
\text { of discrepancy between the meaning and the context }\end{array}$ \\
\hline 5. Consultation & $\begin{array}{l}\text { - Ask online professional translation communities for } \\
\text { help such as «Gorodperevodchikov» } \\
\text { (http://www.trworkshop.net/job/) subject to any } \\
\text { difficulty in defining the meaning of the neologism } \\
\text { - Discuss different meanings of neologisms in the }\end{array}$ \\
\hline
\end{tabular}




\begin{tabular}{|c|c|}
\hline & $\begin{array}{l}\text { training group with the help of active and interactive } \\
\text { methods (brainstorming, case-study, presentations, } \\
\text { etc.) }\end{array}$ \\
\hline 6. Translation & $\begin{array}{l}\text { - Translate the neologism with the help of generally } \\
\text { accepted translation techniques, taking into account its } \\
\text { identified meaning. These include: } \\
\text { calquing is borrowing a word or phrase from another } \\
\text { language while translating its components so as to create a } \\
\text { new lexeme in the target language (for example, } \\
\text { viral marketing - вирусный маркетинг, вирусное } \\
\text { продвижение товара, flea таrket - блошиный рынок) } \\
\text { transliteration is a type of conversion of a text from one } \\
\text { script to another that involves swappingletters in predictable } \\
\text { ways (for example, blog - блог) } \\
\text { transcription is the systematic representation of language } \\
\text { in written form (for example, facebooker - фейсбукер); } \\
\text { descriptive translation is used when none of the } \\
\text { equivalents of the word suits the context (for example, } \\
\text { ObamaCareis an informal term which means US healthcare } \\
\text { reform law that expands and improves access to care and } \\
\text { curbs spending through regulations and taxes. It was passed } \\
\text { during the reign of President Obama). }\end{array}$ \\
\hline
\end{tabular}

To test the effectiveness of the proposed step-by-step action plan for teaching EFL students how to understand and translate neologisms in the economic discourse, we put forward the hypothesis that it develops, first of all, skills to use different types of lexicographic sources such as key reference materials in translation; stimulates the ability to apply translation techniques and transformations; enhance contextual guess and intuition in translation; forms the ability to contextualize the meaning, and then to transfer the content of new lexical units by means of the Russian language.

We conducted the study to test the effectiveness of this step-by-step action plan for teaching EFL students how to understand and translate neologisms in the economic discourse. The research participants were third-year students of International Economic Relations Faculty at Financial University under the Government of RF. Two groups of EFL students were assigned to the experimental group (EG -12 people) and control group (CG-12 people).

The 18 week training conducted for the control group was in accordance with the traditional method of teaching the discipline "ESP" and language learning design. The experimental group were provided with the additional training materials including practice-oriented tasks developed by us (based on authentic economic texts) and aimed at helping students master the learning skills to understand and translate neologisms based on the step-by-step action plan (Table 1). The practice-oriented tasks did not go against the course schedule and language learning design. Authentic texts and text fragments for translation also contained neologisms. The language proficiency level of both groups was Upper-Intermediate.

Translating the texts / text fragments with economic discourse containing neologisms, suggested enhancing the integrated use of translation methods and techniques, taking into account the fact that the text / text fragments represented a single whole in a semantic and structural plan. Below are three examples of text fragments from different authentic sources: 
At the first stage of step-by-step action plan implementation EFL students were given the authentic excerpts to elicit a neologism in the text; to dentify what part of speech and function neologism exercise in the sentence; to identify stylistic and genre peculiarities of the text as well as an overall context. The main requirements to select teaching and learning materials were as follows: keeping them up-to-date, providing EFL students with authentic learning materials and taking into acount the relavance of each fragment selected.

We conducted interviews where EFL students clearly responded to the teachers' choice of the text fragments with economic discourse:

- Material was up-to-date (65\% of respondents);

- The texts assigned were diverse in nature and scope $30 \%$ of respondents);

- Material was challenging, interesting and applicable to the modern life ( $27 \%$ of respondents);

- Those practice-oriented texts enriched the vocabulary and increased the level of confidence (70\% of respondents);

- It was the most efficient way to broaden professional horizons (25\% of respondents).

The example of the authentic text fragmentis given below.

Technology has of course been a huge driver, as tools emerge that allow consumers to see their electricityexpenditure, compare prices, track their health and home energy use - and make the best decisions (or even automate the decision making process) based on this information. We've been tracking a number of trends that have charted the rise and rise of consumer empowerment, more on those later, but we've recently begun to see evidence of the emergence of a new breed of consumer -the hyper-individual. This is not just the consumer who gets the best from their money and time, or the multi-taskersearching for a good deal. This is the confluence of many trends - the consumer who lives in the cloud and who, through the adoption of these new skills, has become one very powerful, super-charged consumer who recognises the value of freely available information and uses it to regain control in the marketplace (BBC News 18th January 2013).

There are four non-equivalent neologisms in the above example, whose understanding and translation are contingent on defining the way of their formation, deep contextual penetration into the meaning of the text, and analysis of lexicographic sources: 1) hyper-individual refers to a person not only working on the Internet, but also transfering all aspects of his social life there; 2) multi-tasker is a person who can solve several tasks at the same time; 3) cloud is a metaphor for the Internet; cloud computing environment; 4) super-charged is energetic.

To assess the level of an adequate understanding and translation of neologisms in the economic discourse at pre-experimental and post-experimental stages EFL students were given the assignments:

- Find neologisms in the text fragments;

- Explain the meaning of the neologisms in English;

- Translate the neologisms into Russian.

The pre-experimental section revealed approximately the same skills to translate economic texts / text fragments, taking into account an understanding and translation of neologisms in both groups.

The results of the survey are shown below. 
Table 2:Pre-experimental and post-experimental results (in persons)

\begin{tabular}{|c|c|c|c|c|c|c|c|}
\hline \multicolumn{3}{|c|}{ Robin Hood tax } & \multicolumn{2}{c|}{\begin{tabular}{c} 
off-gridding \\
\multicolumn{2}{|c|}{}
\end{tabular}} & \multicolumn{2}{c|}{$\begin{array}{c}\text { the squeezed } \\
\text { middle }\end{array}$} & \multicolumn{2}{c|}{$\begin{array}{c}\text { recession-proof } \\
\text { top earners }\end{array}$} \\
\hline CG & EG & CG & EG & CG & EG & CG & EG \\
\hline 5 & 6 & 1 & 1 & 7 & 7 & 5 & 4 \\
\hline 7 & 6 & 11 & 11 & 5 & 5 & 7 & 8 \\
\hline 2 & 1 & 1 & 0 & 4 & 5 & 1 & 3 \\
\hline 10 & 11 & 11 & 12 & 8 & 7 & 11 & 9 \\
\hline 3 & 3 & 1 & 0 & 6 & 7 & 2 & 2 \\
\hline 9 & 9 & 11 & 12 & 6 & 5 & 10 & 10 \\
\hline \multicolumn{7}{|c|}{ Post-experimental results } \\
\hline 6 & 7 & 4 & 5 & 9 & 9 & 7 & 7 \\
\hline 6 & 5 & 8 & 7 & 3 & 3 & 5 & 5 \\
\hline 4 & 4 & 4 & 4 & 8 & 8 & 4 & 5 \\
\hline 8 & 8 & 8 & 8 & 4 & 4 & 8 & 7 \\
\hline 5 & 5 & 3 & 4 & 7 & 7 & 4 & 4 \\
\hline 7 & 7 & 9 & 8 & 5 & 5 & 8 & 8 \\
\hline
\end{tabular}

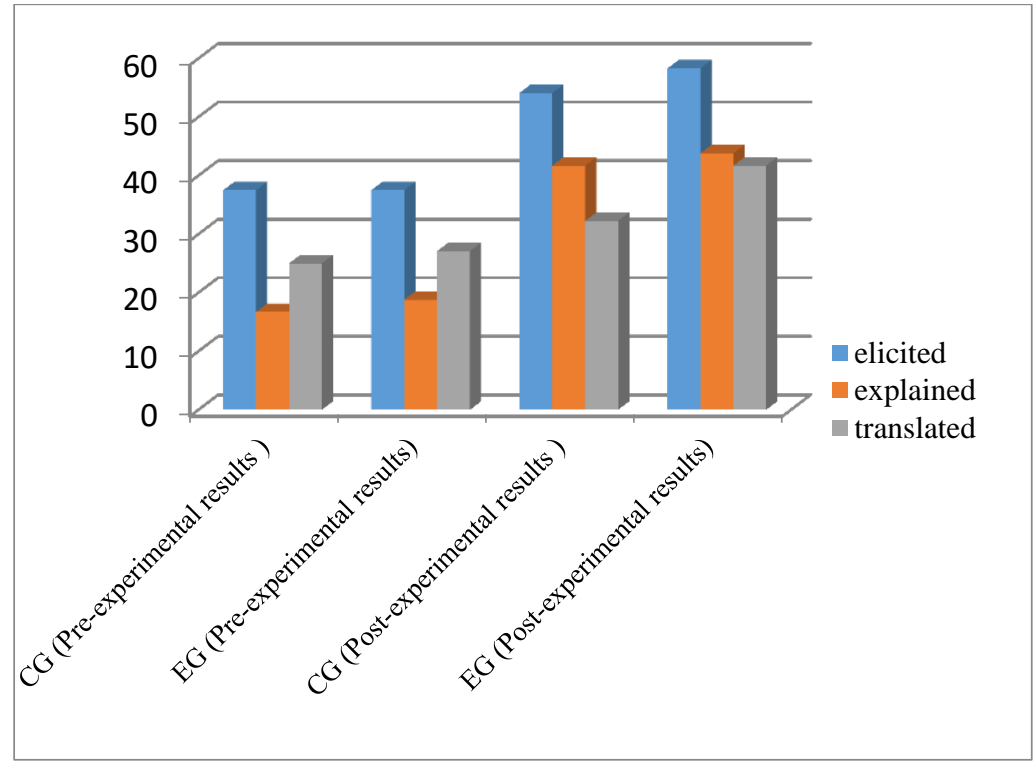

Figure 1: Comparative analysis of pre-experimental and postexperimental results $(\%)$

The post-experimental section has shown that the experimental group demonstrated more confident use of different lexicographic sources. They successfully coped with the transfer of the semantic adequacy of the text fragments taking into account the translation of neologisms and the translation of terminology and vocabulary. It should be noted that there were fewer errors related to the literal translation in the written works of the experimental group. The comparative analysis of pre-experimental and post-experimental resultsrevealed that the compound growth rate of all the indicators influencing the quality of translation done by the experimental group was 3 per cent as compared with the control group, which

XLinguae, Volume 10 Issue 4, October 2017, ISSN 1337-8384, eISSN 2453-711X 
indicates the effectiveness of the proposed step-by-step action plan for teaching EFL students how to understand and translate neologisms in the economic discourse and developed practice-oriented tasks.

\section{Conclusion}

The problem of understanding and translation of neologisms ranks high on the list of challenges students face. It is connected with the fact that no dictionary can keep up with the penetration of new words and terms into all fields of knowledge with the modern, rapid development of science, as well as natural language changedue to the pervasive influenceof technology in our lives. Therefore, teachers need to enable students to determine the meanings of new words taking into account word formation rules and context, whena neologism presented in the text, is not included in the dictionary. In the classroom, neologisms can be used to develop language competence. They can also use and be a source of background knowledge.Mastering a foreign language is not just learning the linguistic material, it is also necessary to reach the level of a native speaker.

Neologisms can be an interesting area for students to work on. Using different examples of neologisms a teacher can present different word-formation models, promoting students' vocabulary growth, improving analytical skills, ability to analyze and adequately understand modern texts of mass media, which are the main sources of new word-formations. The ever changing political, economic, social, technological realities make a noticeable imprint on the vocabulary of newspaper articles and can increase the level of students'interest. It might be an additional stimulus to mastering the learning material. Undoubtedly, vocabulary acquisition should be carefully controlled. Teaching students to be word-conscious requires selection of the lexical units for learning during the seminars. The choice of the lexical units should be performed according to the principles of frequency, normativity and social contribution of the modern world.

Acknowledgement

We are grateful to Alan Mackenzie, Senior Consultant of Norwich Institute for Language Education, Director Transform ELT, who moderated this paper and in that line improved the manuscript significantly.

\section{Bibliograpic references}

ALEKSEEVA, I.S. 2008. Introduction to the Theory and Practice of Translation: a textbook for students of linguistics and philology. St. Petersburg. 354 p. ISBN 978-57695-4392-0

ALGEO, J. 1990. A Short History of New-Word Study/John Algeo. In: Dictionaries. Neology Forum. vol. 16. pp. 1-15.

ARNOLD, I.V. 1966. Semantic structure of the word in modern English language and methodology of the research. Leningrad. Prosveschenije. 192p. ISBN 5-06-001499-1.

AYTO, J. 1995. Lexical life expectancy a prognostic guide. In: Words: Proc. of an Intern. Symp. Lund. pp. 181-189.

BARNHART, D. - METCALF, A. 1998. America in So Many Words. Words That Shaped America. Boston-New York: Houghton Mifflin Co. ISBN-10: 0618002707.

BARNHART, K.D. 1985. Prizes and Pitfalls of Computerized Searching for New Words for Dictionaries. In: Dictionaries, vol.7, pp. 253-260.

BIROVA, J. - KLIMOVA, I.I. - KALUGINA, O. 2016. Some critics on language education assessment. Mathematics Education, vol. 11, n. 7, pp. 2470-2482. ISSN 2468-4945.

COOK, C.P. 2010. Exploiting linguistic knowledge to infer properties of neologisms.

University of Toronto. In: Doctoral dissertation. Available online: 
https://atkinsbookshelf.wordpress.com/tag/how-many-words-enter-the-englishlanguage-each-year/

LAVROVA, N.A. 2010. About some peculiarities of Author's neologisms (occasionalisms). Actual problems of the humanities and natural sciences 195-198 p.

MCDONALD, L. 2005. The Meaning of "e-": Neologisms as Markers of Culture and Technology. TOPIA. In: Canadian Journal of Cultural Studies, vol. 14, pp. 8290.

MESHKOV, O.D. 1986. Semantic aspects of word compounding in English. Available online: http://www.dissercat.com/content/osobennosti-obrazovaniyaneologizmov-so-znacheniem-deyatelya-v-sovremennom-angliiskom-

yazyke\#ixzz3m3qhtBpp

O'DELL, F. 2016. Creating new words: affixation in neologisms. In: ELT Journal, vol. 70(1), pp. 94-99.

PAYACK, J.P. 2008. A Million Words and Counting. How Global English Is Rewriting the World. New York: Citadel. 224 p. ISSN 0951-0893.

RECENT UPDATES TO THE OED. Available online: http://public.oed.com/the-oedtoday/recent-updates-to-the-oed

RETS, I. 2014. Studying the new vocabulary of the Dutch language in the context of globalization. In: Philological sciences. Theoretical and practical questions, vol. 6, pp. 149-152. ISSN 1997-2911.

SARI, M.P. 2013. A stylistic analysis of neologisms in JRR Tolkien's the fellowship of the ring. Doctoral dissertation, UniversitasNegeri Yogyakarta.

SOKOLOVA, G.G. 1983. Transposition of adjectives and nouns. Text-book. Moscow: Vysshayashkola. 175p.

SLEPOVICH, V.C. 2004. Translation Course (English - Russian). Minsk. Tetrasystems. 320 p. ISBN 985-470-174-3

TAG ARCHIVES: HOW MANY WORDS ENTER THE ENGLISH LANGUAGE EACH YEAR. Available online: https://atkinsbookshelf.wordpress.com/tag/howmany-words-enter-the-english-language-each-year/

THE NUMBER OF WORDS IN THE ENGLISH LANGUAGE. Available online: www.languagemonitor.com

THE OXFORD ENGLISH DICTIONARY. Available online: https://en.oxforddictionaries.com/

VINOGRADOV, V.V. 1969. On relationships between lexical and semantic levels with grammatical ones in language structure. In: Thoughts about modern Russian language. Moscow.

VASBIEVA, D.G. - KALUGINA, O.A. 2016. An Analysis of Students' Intercultural Competence Levels in a Non-Linguistic Higher School. In: XLinguae, vol. 9, n. 3, pp.58-69. ISSN 1337-8393.

YASHINA, M.G. - POLYAKOVA, N.V. 2017. Neologisms in Publicistic Discourse of Foreign Language: Methods of Teaching (Based on Italian and French Languages). In: Scientific Dialogue, n. 6. pp. 287-298. ISSN 2227-1295.

ZABOTKINA, V.I. 1989. New vocabulary of modern English. Moscow, Vysshayashkola Publ. 126 p. ISSN 5-06-000206-3.

ZHOU, L. 2016. Neologism in News English. In: Sino-US English Teaching, vol. 13, n. 4 , pp. 292-295. Available online: http://www.davidpublisher.com/Public/uploads/Contribute/570f3d2ade3b9.pdf

Words: 5199

Characters: 35307 (19,62 standard page) 
Prof. Elena M. Galishnikova, $\mathrm{PhD}$

Foreign Language Department in the Sphere of Economy, Business and Finance Kazan (Volga region) Federal University

18 Kremlyovskaya Street

420008 Kazan

Russia

galishnikovaem@mail.ru

Assoc. Prof. Svetlana N. Khalevina, PhD

Senior Lecturer Olga V. Meshcheryakova

Department of Foreign Languages

Financial University under the Government of the Russian Federation

Leningradsky prospect 49

125993 Moscow

Russia

snhalevina@ya.ru

aomeshcheryakova@fa.ru 